\title{
Financial literacy and SME firm performance
}

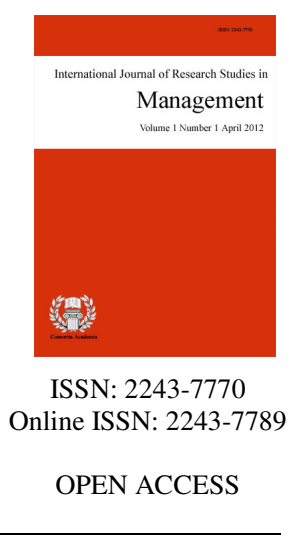

Eniola, Anthony Abiodun $\square$

Department of Business Management, Universiti Malaysia Sarawak (UNIMAS) (tony42003@yahoo.co.uk)

Entebang, Harry

Department of Business Management, Universiti Malaysia Sarawak (UNIMAS) (harryentebang@yahoo.com)

\section{Abstract}

The performance of the SME firm was viewed along the full proportions of financial, strategic and structural development. The socioeconomic function performed by SMEs is widely known in developing and emerging countries. But, in recent times, developing and developed nations have become more and more concerned about the level of financial literacy of the entrepreneur. This has emanated from peculiar to declining public and private to support systems and wide-ranging developments in the financial marketplace. Concern was also intensified by the challenging faced by the SME firm in financial context aided by the recognition that dearth of financial literacy has been one of the many elements responsible for lacks proper knowledge or information about financial decision making and that these decisions could, in turn, have tremendous unexpected consequences. Subsequently, financial literacy is now globally recognized as a major factor of economic and financial stability and development of SMEs for performance. A series of tangible trends underpin the growing worldwide interest in financial literacy as a major life skill, thus, this study set to review the influence of financial literacy on the performance of the SMEs from Nigeria's context. The study will serve as an information because that will promote and orient SMEs firm performance towards financial awareness, knowledge and perceive attitude. Also, the applied significant framework developed will assist SMEs firm owners and policy makers to identify the importance of financial literacy.

Keywords: SME; performance; financial literacy; growth 


\section{Financial literacy and SME firm performance}

\section{Introduction}

The performance and growth of Small and Medium Sized Enterprises (SMEs) have throughout the nations, been of great concern to, among others, development economists, entrepreneurs, governments, venture capital firms, financial institutions and non-governmental organizations (Eniola \& Entebang, 2014). Performance management involves the establishment of a shared understanding about what is to be attained, however, is it going to be attained; and an approach to managing personnel that increases the likelihood of accomplishing success within a consented framework of planned targets, standards and individual and group ability necessities (Armstrong \& Baron, 1998).

Financial literacy, in the brightness of the new business reality, is the capability to adequately oversee financial resources over the life cycle and connect with effectively with financial products and services. Financial literacy is about discernment and makes effective decisions on utilization of financial management (Gavigan, 2010). This is an area that requires knowledge, skill, attitude and experience with goals to deal with the survival of the firm; profit maximization; sales maximization; capturing a particular market share; minimizing staff turnovers and internal conflicts; and maximizing wealth (Jacobs, 2001). It can be among the essential strategic tools to more organize allotments of financial resources and to a considerable financial strength.

In a business, decision-making needs to be rational and be a premised on available information. This implies that it is imperative that manager of business and individual should have a reasonable degree of knowledge related to the available information to make good decisions. Remund (2010) opined that financial literacy is the degree to which one understands important financial concepts and possesses the capacity and confidence to handle personal funds of appropriate, brief period decision-making and solid long-term financial forethought.

A significant obstacle to performance growth of sustainable small and medium scale enterprises (SMEs) throughout the developing world is a lack of knowledge, skills, attitude and awareness to cope and direct the finances of their organization in a hardy, transparent, and professional way. Joo and Grable (2000) stated that the reasons why business people make inappropriate, inadequate and ineffective financial decisions are because of the lack of personal financial knowledge, lack of time to learn about personal financial management, complexities in financial transactions and the extensive variety of choices in financial products/services. Lack of business management skills can magnify financial barriers for SMEs. Low degree of financial literacy can prevent the performance level of SMEs from adequately assessing and understanding different financing provision, and for navigating complex loan application procedures.

The United States has the consumer financial protection bureau (CFPB) and the office of financial education (OFE) with the mandates of promoting financial knowledge and skills in assisting SME firm managers and owners in making the right financial decision. In India, the government established financial stability and development council (FSDC) with responsibilities of educating and counselling entrepreneurial and individual on different sources of financing initiatives. Likewise, Ghana government in 2009 approved a national strategy in collaboration with international agencies on financial literacy and consumer education in assisting SME firm's owners and managers; while, Malaysia government adopted a three pronged approach by establishing financial working committee to oversee the financial literacy program for SME firms' owners and individual in (i) proper sensitizing and disseminating of information on financial products using the print media, booklets, internet via different website and third party publication; (ii) institutional programs in all facets of educational system about money management; and (iii) outreach programs targeting rural folks, women, disable people with regular workshop and briefing sections (Ketley, Lightfoot, Jakubec, \& Little, 2012). 
According to Ketley et al. (2012) and CBN (2012), Nigerian lack financial literacy, and more than $46.3 \%$ did not have access to financial services and lag behind some developing and developed countries. This has been a concern intense challenge faced by the SME firm in the country with the recognition that lack of financial literacy was one of the factors contributing to ill-informed financial decisions and that these decisions could, in turn, had a tremendous negative spill-overs (OECD, 2013). A series of tangible trends underpin the rising global interest in financial literacy as a key life skill. Thus, this study set to review the influence of financial literacy on the of SMEs firm performance in Nigeria.

\section{Conceptual}

A review of the literature on small and medium enterprises (SMEs) shows that the definition of SMEs significantly varies from country to country depending on factors such as the country's; number of employees, the value of fixed assets, production capacity, basic characteristics of the inputs, level of technology used, capital employed, management characteristics, economic development, and the particular problems experienced by SMEs (Eniola \& Entebang, 2015b). Across the African continent, research by the IFC suggests that $90 \%$ of all MSMEs is informal or micro, with the remaining $10 \%$ being the formal SMEs ( $8.6 \%$ are small and $1.4 \%$ medium) (IFC, 2010; Ketley et al., 2012). In Nigeria, the National Policy on Micro, Small and Medium Enterprises (MSMEs) define micro enterprises as employing less than 10 people with assets (excluding land and buildings) of less than $\mathrm{N} 5$ million, small enterprises as between 10-49 employees and assets between $\mathrm{N} 5$ - N 50 million, whilst medium enterprises are those with between 50 and 199 employees and assets between $\mathrm{N} 50-\mathrm{N}$ 500 million.

\subsection{Financial Literacy}

One of the striking things about the literature is that financial literacy has been variably defined as a specific form of knowledge, the ability or skills to apply that knowledge, perceived knowledge, good financial behavior, and even financial experiences (Hung, Parker, \& Yoong, 2009). Financial literacy as sufficient knowledge about facts on personal finances and is the key to personal financial management (Garman \& Forgue, 2002). Their study likewise reviews the lack of knowledge in personal finance, intricate financial situations, in addition to a large range of choices for making decisions on financing, and time constraints on learning about personal finance which is a barrier to financial literacy.

Many researchers have defined financial literacy in many studies in the area of personal finance; many fail to define the concept financial literacy properly because it does not capture the manager and the business people. Gitman (2003) outlined financing provision and indicates that financial service is the section that will include the delivery of financial products to individuals. Financing literacy is listed as one of the critical managerial competencies in SMEs firm and development (Spinelli, Timmons, \& Adams, 2011). Most scholars agree that entrepreneurs, regardless of their age, are consistently engaged in decision-making activities concerning resource procurement, allocation and utilization. Such activities almost always have financial consequences and thus, in order to be effective, entrepreneurs must be financially literate (Oseifuah, 2010). There is the only reference made to the importance of managing money and the author only describes the management process of individual households, but there is no clear description of SME owners/manager financial literacy.

However, there are definitions of financial literacy specifically addressed to managers and business people. A financially literate SME owner/manager was defined as someone that knows what are the most suitable financing decisions on the business performance at the various growth stages of the business; knows where to obtain the most suitable products and services; and interacts with confidence with the suppliers of these products and services (USAID, 2009). Likewise, Marriott and Mellett (1996) defined the manager's ability to understand and analyze financial information and act accordingly. Lusardi and Tufano (2009) emphasized on managers' ability and decision-making aspect of financial literacy. Likewise, they target on a particular form of financial literacy-debt literacy. Moore (2003) goes far as including practical experience, on the contention that it provides 
Eniola, A. A., \& Entebang, H.

the basis for knowledge and other faces of financial literacy. In the present paper, financial literacy is conceptually of how firms manage and strategize financial knowledge, which significantly affect decision makers' behaviors, awareness and attitudes, concerning sound decision making and eventually achieving organizational performance.

\subsection{Firm Performance}

The concept of performance in relation to SMEs, particularly, the definition of performance will be discussed. Performance may have two strategic outcomes that are often referred to in the literature as firm success or failure (Eniola \& Entebang, 2015a). In the management field, firm performance can be interpreted as measures of good or indifferent management (Jennings \& Beaver, 1997; Sefiani \& Bown, 2013), but it may occur to other reasons such as luck. The effects of a firm's performance depend on whether the firm has attained its goals or not (Davidsson, 2004).

Firm performance is a focal phenomenon in business management. It has been proposed in the literature (Barney, 2002). The general performance of the organization depends on the correct management at the three levels of management (Eniola \& Entebang, 2015a). Performance can be characterized as the firm's ability to create acceptable outcomes and actions. However, performance seems to be conceptualized, rationalized and measured in different ways, thus making cross- comparison difficult.

According to Eniola and Entebang (2015a), performance is commonly employed as an index of a firm's health over a dedicated period. This puts performance as one of the key issues of SMEs. The capacity to institute change in management of perceiving market opportunities, adapting to the environment, and possessing certain managerial factors, product innovations, creativity, pro-activeness, technological change, networking, are all critical factors to bringing about strategic improvement in firm performance. Performance encompasses various meanings, including growth, survival, success and competitiveness. Performance can be characterized as the firm's ability to create acceptable outcomes and actions (Eniola \& Entebang, 2015a).

\subsection{Theory and hypothesis Development - Resource base view}

This study attracts support from resource based theory as a result of it being extensively applied within the business management and entrepreneurship literature. It has been indicated earlier by some researchers that presently, the foremost effective framework of understanding strategic management is a resource-based theory of the firm. Resource-based theorists have explicit strategic resources as the defining attribute of assets that create sustained competitive advantage (Barney, Wright, \& Ketchen, 2001). It chanced that the business owner and manager of the SME did not yield the proper attention to the strategic management of the SME particular, when it is declared important and essential for the firm. In line with RBV advocate, it is rather more viable to take advantage of external opportunities using existing resources in a new way alternatively than seeking to gather new capabilities for every exclusive possibility. Earlier researchers have developed the most eminent exponent of the RBV, proposed that a firm use of ,idiosyncratic, immobile" resources as the source of sustained competitive capability that transforms into better superior performance (Eniola \& Entebang, 2014).

Resources are anything that might be thought of as a strength or weakness of a given firm, comprising tangible and intangible assets. Tangible resources include financial capital (e.g., equity capital, debt capital, retained earnings) and physical capital (e.g., machinery \& buildings). Intangible resources consist of entrepreneurial knowledge, skills, experiences, organizational procedures and reputation, among others (Eniola \& Entebang, 2014).

The resource based view (RBV) suggests that lack of financial, human, organizational resources and capabilities reduce the firm innovation activities (Hewitt-Dundas, 2006). The inaccessibility of financial resources is a major impediment to the development of SMEs, particularly because it prevents them from acquiring the new technology that would make them more productive and more competitive. Dundas conducted 
a panel data analysis of Irish firms and found that lacks of access to finance are a major constraint to the firm innovation activities. Further, Ihua (2009); Wiklund and Shepherd (2005), stated that financing is an important resource for firm performance and they have empirically tested that small business performance is positively influenced by external financing facilities available to firms.

Current research in both strategic business management and finance has begun to evaluate the correlation between firm strategy and its capital structure (Eniola \& Entebang, 2014). In sustaining a firm's competitive advantage, financing is important. Moreover, researchers cited that the two facets of a firm may be closely akin to each other (Gertner, Gibbons, \& Scharfstein, 1988; Williamson \& Asla, 2009).

Balakrishnan and Fox (1993) opined that ability of the firm to manage its relationships with lenders becomes a key source of competitive advantage. Accordingly, human resources in terms of experience and capabilities, trust, managerial skills, practices and procedures of the top and middle management, administrative and production employees were also able to elucidate the extent of the firm competitive advantage and the resulting SME firm performance. Experiential resources such as product reputations, manufacturing experience and brand name can account for the variation in firm competitive advantage and performance (Eniola \& Entebang, 2014; Eniola, Entebang, \& Sakariyau, 2015).

Barney (1991) presented an all-inclusive framework required to generate sustainable superior performance and take apart the firm resource characteristics needed. Value, rareness, inimitability, and substitutability were used as proposed criteria to evaluate the economic implications of the resources. Value as part of strategic resources, mentions the extent to which the firm's composite possible resources and fits with the outer environment in order that the firm can create the most opportunities or counteract risk in the competitive environment. Rareness is about the resources in the factor markets in a physical or perceived physical rareness manner. Inevitability is the continuation of imperfect element markets by way of understanding information asymmetry such those resources cannot be received or recreated by means of other corporations without a cost disadvantage. Afterwards, the framework additionally considers whether or not the firms are substitutable by competitors. Hunt and Morgan (1996) proposed that potential resources can be most usefully categorized as financial, physical, legal, human, organizational, informational, and relational. As duly noted by Barney (1991); Barney and Hesterly (2015), firm's resources include all assets, capabilities, organizational processes, knowledge, firm's feature, information, etc. controlled by a firm that enable the firm to conceive and devise strategies that improve its efficiency and effectiveness. The relationship between firm's resources and competitive advantage is significantly enhanced by attributes and elements such as value, rareness, inimitable and non-substitutable, i.e., the VRIN factor.

Barney (1991); Barney and Hesterly (2015), stated that human capital resources include the training, knowledge, experience, judgment, intelligence, attitude, relationships, and insights of individual managers in a firm. Evidence of previous empirical studies of organizational and entrepreneurial learning suggests that investment decision making in SMEs is on the basis of experiential learning, rather than formalized methods. Financial literacy as an aspect of human capital shows that entrepreneur with higher general and specific human capital can be expected to show higher levels of performance than those with lower levels of general and specific human capital (Eniola et al., 2015). Experience and knowledge are extremely important, as it provides time to recognize opportunities, develop contacts and learn how to access and to interact with funders, including bank managers and venture capitalists. Thus, entrepreneurial human capital is substantial and consequential to entrepreneurial growth. Although some studies report that only a small number of SME managers employ the resulting knowledge in a proactive way to build competitive advantage (Matlay, 2000); other studies find that as firms move from a higher-level learning style, this is accompanied by competence enhancement that can lead to greater organizational capability (Chaston, Badger, Mangles, \& Sadler-Smith, 2001).

Capabilities specify a firm's capacity to set up and bring together different resources, mostly in combinations, using organizational processes, to affect a superior performance (Amit \& Schoemaker, 1993; 
Grant, 1996). They are information-based, firm-specific that is essentially an intangible mechanism developed over time through intricate interactions among the firm's resources (Amit \& Schoemaker, 1993; Conner, 1991; Prahalad \& Hamel, 2006). They can conceivably be thought as the knowledge, attitude and awareness generated by the firm to enhanced different source of resources (financing and non-financing) as well as strategic resilience and aegis for the firm superior performance.

The competitive capability is a base of a good strategy, and a good one creates superior performance (Analoui \& Karami, 2003). However, more often than not, the first scenario that competitive capability will lead to superior performance will be successful given the fact that organization concentrated their competitive strategy towards enhancing their resource pool (Fahy, 2000). Indeed, as Barney, argued that firm's resources which include all its assets, capabilities, organizational processes, firm's attributes, information, knowledge, etc., possessed and/or managed by a firm can ultimately change the firm to develop and implement strategies that will improve its efficiency and effectiveness, hence superior firm's performance. Further, Giménez and Ventura (2003) analyzed the relationship between internal and external integration processes, and their significant effect on firms' performance and competitive advantage.

Accordingly, Eniola and Entebang (2014), stated that a firm that formulates and implements a strategy that leads to superior performance relative to other competitors in the same industry or the industry averages possess a competitive advantage. From one perspective, it is essential for SMEs to acquire, keep up and extend via the internal and external financial resources they may have and insure. Mintzberg classified ten managerial roles in three categories: interpersonal, informational, and decisional. Mintzberg's general portrayal of managerial work for competitive advantage was confirmed in later studies. Then again, SMEs need to do the outer evaluation to become aware of the opportunities and threats and to identify the distinctive competencies. The resource-based theory postulated that the firm resources hinge on the thorough competitiveness, it possesses that separate it from its competitors, durable, severe to imitate and substitute.

According to Bosma and Harding (2006), many SMEs firms fail because they lack financial literacy, insufficient business acuity, as well as poor financial literacy, undermines entrepreneurial activity. Most scholars agree that entrepreneurs, regardless of their age, consistently engaged in decision-making activities concerning resource procurement, allocation and utilization. Such activities almost always have financial consequences and thus, in order to be effective, entrepreneurs must be financially literate (Oseifuah, 2010).

Drexler, Fischer, and Schoar (2014) posited that entrepreneurs usually suffer from sufficient financial literacy to make the complex financial decisions they face. This is unfortunate, since according to Oseifuah (2010), 'financial literacy among youth entrepreneur contributes meaningfully to their entrepreneurship skills.' Entrepreneurs wanting to grow need to feel confident of their finances, as well be adequately informed (Kotzè \& Smit, 2008). If the owners-managers are illiterate concerning their organizational finances, the financial knowledge of their firms will also be lacking and will lead to reduction in innovation that can transform into competitive capability, unable to accessing different sources of financing provision due to non-awareness and this attitude will lead to possible failures of SMEs (Kotzè \& Smit, 2008). What all these perspectives seem to agree on is that entrepreneurs suffer from a lack of financial literacy and such deficiency undermines the probability of getting different sources of financing that can result into competitive capability and firm superior performance.

In effect, the RBV is a statement about how firms actually operate. It is based on the assumption that across firms, resources are heterogeneously allocated, and that this distribution is long lasting (Mac an Bhaird, 2010). In RBV model, resources are given assigned vital role in assisting firms to attain higher organizational superior performance. Much evidence indicates that firm with less financially literate is likely to stand more demanding situations with regard to performance. Greenspan (2002) argued that financial literacy helps to inculcate individuals with the financial knowledge necessary to create a household planning, initiate savings plan, and make strategic investment decisions. Proper application of that knowledge helps SME owners to meet their 
financial obligations through to wise planning, resource allocation and financial service demand so as to deriving maximum utility. Hilgert, Hogarth, and Beverly (2003) asserted that individuals with lower degrees of financial literacy may have lowered degrees of education, be less interested in financial matters, and be poorer. This means that the level of an individual's financial knowledge tends to influence the awareness that in turn affects the individual's financial attitude (Baron \& Kenny, 1986).

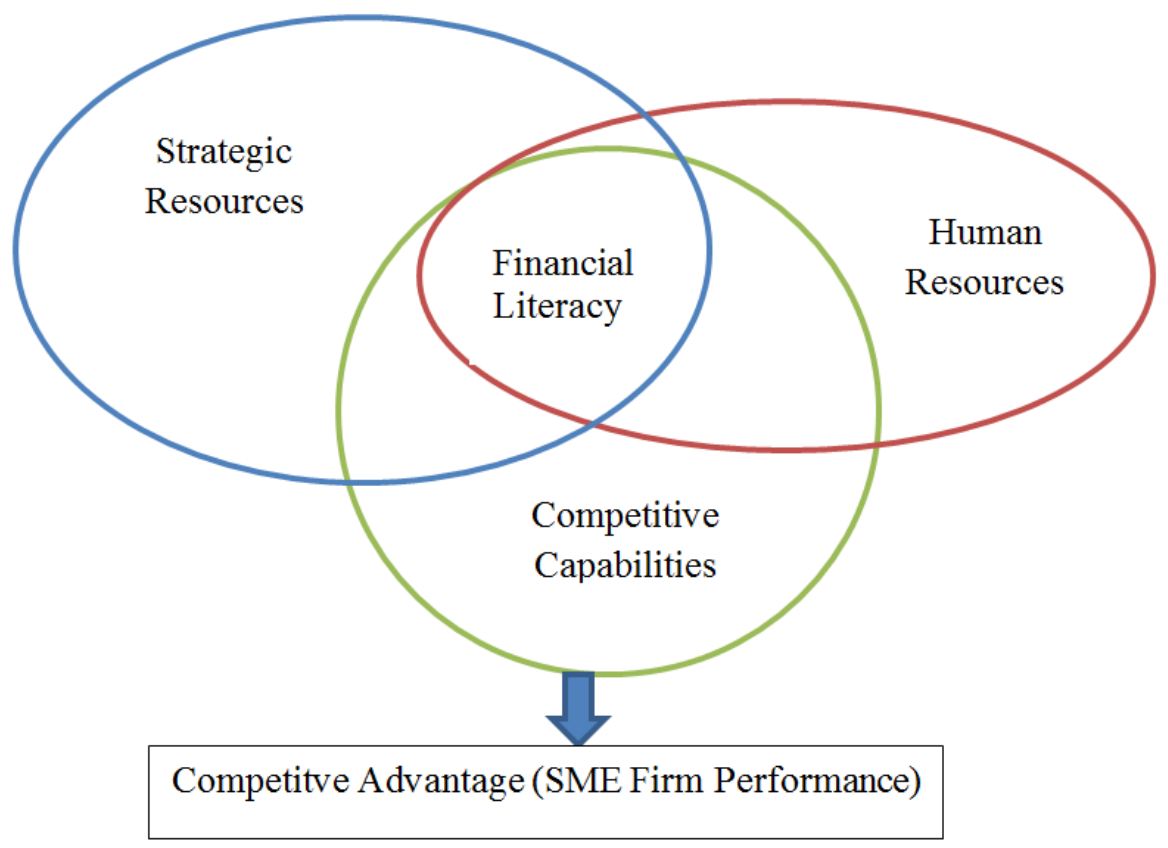

Source: Adapted from Sulaiman (2014)

\subsection{Financial Literacy and its Influence on SME Firm Performance}

Positive relationships between financial literacy and performance have been noted by a number of researchers (Hilgert et al., 2003; Huston, 2010; Kidwell \& Turrisi, 2004; Lusardi, Mitchell, \& Curto, 2010; Piprek \& Coetzee, 2004). Financial resources are essential resources for obtaining both tangible and intangible resources and arranging other resources (Alsos, Isaksen, \& Ljunggren, 2006; Brinckmann, Salomo, \& Gemuenden, 2011). The concept of financial literacy as comprising three dimensions in knowledge (Lusardi \& Bassa Scheresberg, 2013); attitude (Sabri \& MacDonald, 2010); and awareness (Rahmandoust, shah, Norouzi, Hakimpoor, \& Khani, 2011). Knowledge is about understanding how business performance and business condition are measured using the mental model to facilitate, support, or enrich decision-making (Lusardi \& Michell, 2007; Moore, 2003).

Lusardi and Michell (2006) suggested that financial literacy is needed to create a measure of financial competence, i.e., to stay knowledgeable about financial matters. These literate people are more participating in financial markets because they know financial matters. Lusardi and Bassa Scheresberg (2013) examined the impact of financial literacy and high cost of the borrowers. The result indicated that there is a relationship between financial literacy and low-cost borrowers. Most high-cost borrowers display very low levels of financial literacy, lack knowledge of basic financial concepts, which affect their performance level in a business. Tamimi and Kalli (2009) examined the impact of financial literacy on financial knowledge. Their results showed that the field of individual activities affects the financial literacy level and people that invest in financial awareness have a higher level of financial literacy. The review also showed that male gender possesses higher financial literacy 
and income, age and education level are followed by a higher level of financial literacy.

Braunstein and Welch (2002) pointed out that obtaining additional information can lead to improved financial attitude. Morgan, Kaleka, and Katsikeas (2004) concentrated on the importance of linkages among obtainable resources and capabilities, competitive strategy decisions, competitive advantage and performance outcomes. These factors are conceptualized in terms of experiential, financial, scale \& physical resources; product development, networking and knowledge potential; cost-based advantage; the lowest cost of operation, marketing, product differentiation; product-based, economically, distributor \& end-user. Kidwell and Turrisi (2004) indicated that firms with better financial knowledge keep detailed firm financial records and have a more competitive advantage in accessing external funding than their counterparts who keep not. While, Hilgert et al. (2003) insisted that a strong link between financial knowledge and financial behavior subsists.

Financial knowledge would affect in increase firm total sources of financing (Marcolin \& Abraham, 2006). Moore (2003) elucidated that literacy or knowledge is gained via practical experience and active integration of knowledge. In other words, people will become more sophisticated in terms of finance when they are more literate. Likewise, another researcher, emphasized that an individual or organization who had financial literacy, knowledge and ability to put to use this knowledge, may not show the assume behavior or enhance his or her financial well-being as a result of other influences such as cognitive and behavior that is biased, self-control problems, family, peers, economic and institutional conditions that may affect the financial habits and financial well-being (Huston, 2010). However, researchers agreed that there is no established instrument applied to measure financial literacy and that financial literacy cannot be measured directly.

Awareness comes under the sector of the managerial, where it is the duty of the manager to look after organization for the well-being of the business. The ability to read, analyzes, manage and discuss various financial conditions that eventually lead to individuals' economic well-being (Lusardi \& Tufano, 2009; Rahmandoust et al., 2011; Vitt \& Ward, 2000). Deakins, Logan, and Steele (2001) found that owners-managers have different approaches concerning business planning. Fundamentally planning was indispensable to those firms under growing growth and periods of rapid changes. However (Lusardi \& Tufano, 2009); Mandell (2007), emphasized on ability and decision-making aspect of financial literacy. Berman and Knight (2008) definitely stated that financial literacy needs to become part of every business culture. Audet and St-Jean (2007) discovered that the SME owner/managers, who perceived more and aware about the external service providers, make use of those services more than SME owner/managers who did not hold any information about these services.

While attitude is related to risk-taking, it is the firm consciously committing resources to projects with a chance of higher returns but may also entail a possibility of high failure (Lumpkin \& Dess, 1996). Nevertheless, risk-taking is also usually linked with entrepreneurial behavior and that mainly successful entrepreneurs are risk-takers (Kuratko \& Hodgetts, 2001). Lusardi and Tufano (2009) likewise concentrated on a particular pattern of financial literacy-debt literacy. Moore (2003) goes far as incorporating handy experience in the argument that it provides the basis of knowledge and different perspectives financial related proficiency. Cude (2010) examined effective factors of people's financial literacy. He observed that more work experience, higher levels of education, risk appetite, parental occupation, higher age, family income, and training attending classes will boost financial literacy. Bond and Meghir (1994) opined that credit terms also determined the extent to which SMEs access finance. They noted that when credit terms are favorable the SMEs managers' attitudes to accessing that credit tends to be positive and they are encouraged to borrow and, therefore, expansion of the capital base leading to increasing business activity. In this study, it is signified that the most successful people in their line of work and personal lives are highly financially literate. Their financial concerns were well lower and they had long-term savings and investments and triggered a better future with more long-term vision. Financial literacy is reported having a negative relationship to financial constraints (Sabri \& MacDonald, 2010). 


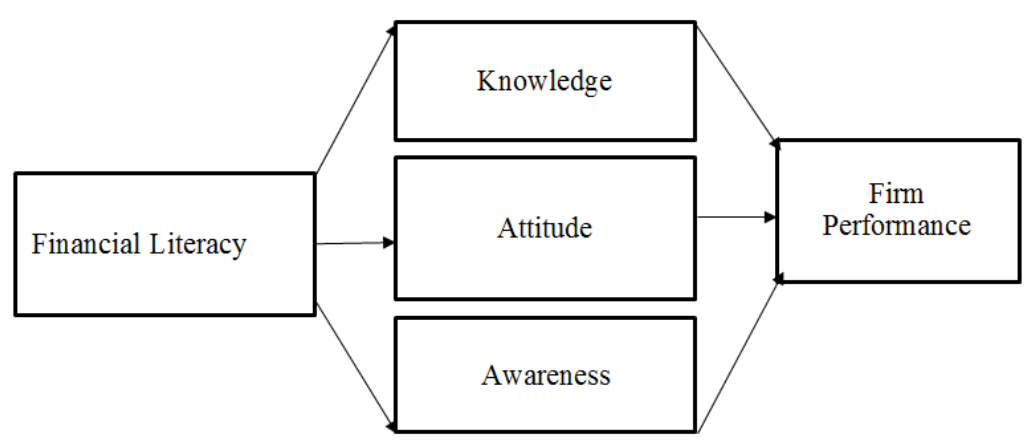

Figure 2. Framework

Source: Prepared by the author

\section{Conclusion}

This research is based on resource based view theory to show the influence of financial literacy on the performance of small and medium enterprises (SMEs) in Nigeria. The resource-based theory is a basis of much what is taught today. In addition, scholars in strategic management actively pursue resource based research in the contemporary era and it is being projected into the future of a series of exciting theoretical and empirical developments. The performance of SME firms leads to some critical issues and many studies dealt with the subject matter from many angles. Current study discusses one of the important issues: financial literacy is a particular problem of small and medium enterprises (SMEs), company tend to have much higher rates of job growth, but also are more likely to go out of business or remain stunted due to institutional and financial literacy problems. The significance of the small and medium enterprises (SMEs) sector is acknowledged in economies worldwide, regardless of the economy's advancing stage. The contribution en routes performance growth, employment creation and social progress is valued greatly and small and medium enterprises (SMEs) consider as a crucial factor in a successful formula for attaining economic growth. This review is one of the few studies that approached this subject. Thus, the lack of studies in this respect is due to the complex and the enterprising nature of the small and medium enterprises (SMEs) and the different objectives, especially in Nigeria.

\section{References}

Alsos, G., Isaksen, E., \& Ljunggren, E. (2006). New venture financing and subsequent business growth in men and women-led businesses. Entrepreneurship Theory and Practice, 30, 667-686. http://dx.doi.org/10.1111/j.1540-6520.2006.00141.x

Amit, R., \& Schoemaker, P. J. H. (1993). Strategic assets and organizational rent. Strategic Management Journal, 14(1), 33-46. http://dx.doi.org/10.1002/smj.4250140105

Analoui, F., \& Karami, A. (2003). Strategic management in small and medium enterprises. Australia: Thomson Learning.

Armstrong, M., \& Baron, A. (1998). Performance management: The new realities. London: Institute of Personnel and Development.

Audet, J., \& St-Jean, E. (2007). Factors affecting the use of public support services by SME owners: Evidence from a periphery region of Canada. Journal of Developmental Entrepreneurship, 12(2), 165-180. http://dx.doi.org/10.1142/S1084946707000629

Balakrishnan, S., \& Fox, I. (1993). Asset specificity, firm heterogeneity and capital structure. Strategic Management Journal, 14(1), 3-16. http://dx.doi.org/10.1002/smj.4250140103

Barney, J. B. (1991). Firm Resources and Sustained Competitive Advantage. Journal of Management, 17, 99-120. http://dx.doi.org/10.1177/014920639101700108

Barney, J. B. (2002). Gaining and sustaining competitive advantage (2nd ed.). Upper Saddle River, NJ: Prentice Hall. 
Eniola, A. A., \& Entebang, H.

Barney, J. B., \& Hesterly, W. S. (2015). Strategic management and competitive advantage: Concepts and cases. Prentice Hall.

Barney, J. B., Wright, M., \& Ketchen, D. J. (2001). The resource-based view of the firm: Ten years after 1991. Journal of Management, 27(6), 625-641. http://dx.doi.org/10.1177/014920630102700601

Baron, R. M., \& Kenny, D. A. (1986). The moderator-mediator variable distinction in social psychological research: Conceptual, strategic, and statistical considerations. Journal of Personality and Social Psychology, 51(6), 1173-1182. http://dx.doi.org/10.1037/0022-3514.51.6.1173

Berman, K., \& Knight, J. (2008). Financial intelligence for entrepreneurs: What you really need to know about the numbers. Boston, Mass.: Harvard Business Press.

Bond, S., \& Meghir, C. (1994). Financial Constraints and Company Investment. Fiscal Studies, 15(2), 1-18. http://dx.doi.org/10.1111/j.1475-5890.1994.tb00194.x

Bosma, N., \& Harding, R. (2006). Global entrepreneurship monitor: GEM 2006 summary results: Babson College London Business School.

Braunstein, S., \& Welch, C. (2002). Financial literacy: An overview of practice, research, and policy (pp. 445-457.): Federal Reserve Bulletin.

Brinckmann, J., Salomo, S., \& Gemuenden, H. G. (2011). Financial management competence of founding teams and growth of new technology-based firms. Entrepreneurship Theory and Practice, 35(2), 217-243. http://dx.doi.org/10.1111/j.1540-6520.2009.00362.x

CBN. (2012). Exposure draft of framework for financial literacy in Nigeria. Abuja: Central Bank of Nigeria (CBN).

Chaston, I., Badger, B., Mangles, T., \& Sadler-Smith, E. (2001). Organisational learning style, competencies and learning systems in small, UK manufacturing firms. International Journal of Operations \& Production Management, 21(11), 1417-1432. http://dx.doi.org/10.1108/EUM0000000006224

Conner, K. R. (1991). A historical comparison of resource-based theory and five schools of thought within industrial organization economics: Do we have a new theory of the firm? Journal of Management, 17(1), 121-154. http://dx.doi.org/10.1177/014920639101700109

Cude, B. J. (2010). Financial literacy 501. Journal of consumer affairs: Official publication of the american council on consumer interests, 44(2), 271-275.

Davidsson, P. (2004). Researching entrepreneurship. Boston, MA: Springer Science Business Media Inc.

Deakins, D., Logan, D., \& Steele, L. (2001). The financial management of the small enterprise. London: Certified Accountants Educational Trust.

Drexler, A., Fischer, G., \& Schoar, A. (2014). Keeping it simple: Financial literacy and rules of thumb. American Economic Journal: Applied Economics, 6(2), 1-31.

Eniola, A. A., \& Entebang, H. (2014). SME firms performance in Nigeria: Competitive advantage and its impact. International Journal of Research Studies in Management, 3(2), 75-86. http://dx.doi.org/10.5861/ijrsm.2014.854

Eniola, A. A., \& Entebang, H. (2015a). Government policy and performance of small and medium business management. International Journal of Academic Research in Business and Social Sciences, 5(2), 237-248. http://dx.doi.org/10.6007/IJARBSS/v5-i2/1481

Eniola, A. A., \& Entebang, H. (2015b). SME firm performance-financial innovation and challenges. Procedia Social and Behavioral Sciences, 195, 334-342. http://dx.doi.org/10.1016/j.sbspro.2015.06.361

Eniola, A. A., Entebang, H., \& Sakariyau, O. B. (2015). Small and medium scale business performance in Nigeria: Challenges faced from an intellectual capital perspective. International Journal of Research Studies in Management, 4(1), 57-71. http://dx.doi.org/10.5861/ijrsm.2015.964

Fahy, J. (2000). The resource-based view of the firm: some stumbling-blocks on the road to understanding sustainable competitive advantage. Journal of European Industrial Training, 24(2/3/4), 94-104.

Garman, E. T., \& Forgue, R. E. (2002). Personal finance. Lexington, Ky.: Lexington Volunteer Recording Unit.

Gavigan, K. (2010). Show me the money resources:Financial literacy for 21 st century learners (pp. 28(25):24-27.): Library Media Connection.

Gertner, R., Gibbons, R., \& Scharfstein, D. (1988). Simultaneous signalling to the capital and product markets. 
The RAND Journal of Economics, 19(2), 173. http://dx.doi.org/10.2307/2555698

Giménez, C., \& Ventura, E. (2003). Supply chain management as a competitive advantage in the Spanish grocery sector. The International Journal of Logistics Management, 14(1), 77-88. http://dx.doi.org/10.1108/09574090310806558

Gitman, L. J. (2003). Principles of managerial finance (10th ed.). Boston, MA: Addison-Wesley Pub.

Grant, R. M. (1996). Toward a knowledge-based theory of the firm. Strategic Management Journal, 17(S2), 109-122. http://dx.doi.org/10.1002/smj.4250171110

Greenspan, A. (2002). Financial Literacy: A tool for economic progress. Futurist, 36, 37-41.

Hewitt-Dundas, N. (2006). Resource and capability constraints to innovation in small and large plants. Small Business Economics, 26(3), 257-277. http://dx.doi.org/10.1007/s11187-005-2140-3

Hilgert, M. A., Hogarth, J. M., \& Beverly, S. G. (2003). Household financial management: The connection between knowledge and behavior. Federal Reserve Bulletin, 89(7), 310-322.

Hung, A. A., Parker, A. M., \& Yoong, J. (2009). Defining and measuring financial literacy. Retrieved from http://www.rand.org/content/dam/rand/pubs/working_papers/2009/RAND_WR708.pdf

Hunt, S. D., \& Morgan, R. M. (1996). The resource-advantage theory of competition: dynamics, path dependencies, and evolutionary dimensions. The Journal of Marketing, 107-114. http://dx.doi.org/10.2307/1251905

Huston, S. J. (2010). Measuring financial literacy. Journal of Consumer Affairs, 44(2), 296-316. http://dx.doi.org/10.1111/j.1745-6606.2010.01170.x

IFC. (2010). Scaling-up sme access to financial services in the developing world: Financial inclusion experts grouplsme finance sub-group: International finance corporation. World Bank Group.

Ihua, U. B. (2009). SMEs key failure-factors: A comparison between the United Kingdom and Nigeria. Journal of Social Sciences, 18(3), 199-207.

Jacobs, A. (2001). Financial Management IV (FMA 401-V): Study guide 1 (3rd ed.). Pretoria: Technikon S.A.

Jennings, P., \& Beaver, G. (1997). The performance and competitive advantage of small firms: A management perspective. International Small Business Journal, 15(2), 63-28. http://dx.doi.org/10.1177/0266242697152004

Joo, S. H., \& Grable, J. E. (2000). Improving employee productivity: The role of financial counseling and education. Journal of Employment Counseling, 37(1), 2-15. http://dx.doi.org/10.1002/j.2161-1920.2000.tb01022.x

Ketley, R., Lightfoot, N., Jakubec, M., \& Little, M. (2012). Review of government interventions that promote access to credit for Micro, Small and Medium Enterprises (SMEs) in Nigeria. Retrieved from http://www.efina.org.ng/assets/Documents/Review-of-government-interventions-that-promote-access-to -credit-for-MSMEs-in-Nigeria.pdf

Kidwell, B., \& Turrisi, R. (2004). An examination of college student money management tendencies. Journal of economic psychology : research in economic psychology and behavioral economics, 25(5), 601-616.

Kotzè, L., \& Smit, A. (2008). Personal financial literacy and personal debt management: the potential relationships with new venture creation. South African Journal of Entrepreneurship and Small Business, $1(1), 35-50$.

Kuratko, D. F., \& Hodgetts, R. M. (2001). Entrepreneurship: A contemporary approach (5th ed.). Australia: South-Western Thomson Learning.

Lumpkin, G. T., \& Dess, G. G. (1996). Clarifying the entrepreneurial orientation construct and linking it to performance. The Academy of Management Review, 2l(1), 135.

Lusardi, A., \& Bassa Scheresberg, C. D. (2013). Financial literacy and high-cost borrowing in the United States. Cambridge Mass. http://dx.doi.org/10.3386/w18969

Lusardi, A., \& Michell, O. S. (2006). Financial literacy and planning: Implications for retirement wellbeing. Wharton School, University of Pennsylvania: Pension Research Council Working Paper n. 1.

Lusardi, A., \& Michell, O. S. (2007). Baby boomer retirement security: The roles of planning, financial literacy, and housing wealth. Journal of Monetary Economics, 54, 204-205.

http://dx.doi.org/10.1016/j.jmoneco.2006.12.001 
Eniola, A. A., \& Entebang, H.

Lusardi, A., \& Tufano, P. (2009). Debt literacy, financial experiences, and overindebtedness. Cambridge Mass. http://dx.doi.org/10.3386/w14808

Lusardi, A., Mitchell, O. S., \& Curto, V. (2010). Financial literacy among the young. Journal of consumer affairs: Official publication of the American Council on Consumer Interests, 44(2), 358-380.

Mac an Bhaird, C. (2010). Firm financing: A resource based view. London.

Mandell, L. (2007). Financial literacy of high school students. In J. J. Xiao (Ed.), Handbook of consumer finance research (pp. 163-183). New York: Springer.

Marcolin, S., \& Abraham, A. (2006). Financial literacy research: Current literature and future opportunities. Paper presented at the 3rd international conference of contemporary business, Leura.

Marriott, D. N., \& Mellett, H. J. (1996). Health care managers' financial skills: measurement, analysis and implications. Accounting Education: An International Journal, 5(1), 61-74. http://dx.doi.org/10.1080/09639289600000006

Matlay, H. (2000). Organisational learning in small learning organisations: an empirical overview. Education + Training, 42(4/5), 202-211.

Moore, D. (2003). Survey of financial literacy in washington state: knowledge, behavior, attitudes, and experiences. Technical Report n. 03-39,Social and Economic Sciences Research Center,Washington State University.

Morgan, N. A., Kaleka, A., \& Katsikeas, C. S. (2004). Antecedents of export venture performance: A theoretical model and empirical assessment. Journal of Marketing, 68(1), 90-108. http://dx.doi.org/10.1509/jmkg.68.1.90.24028

OECD. (2013). PISA 2012 assessment and analytical framework: mathematics, reading, science, problem solving and financial literacy. OECD Publishing.

Oseifuah, K. E. (2010). Financial literacy and youth entrepreneurship in South Africa. African Journal of Economic and Management Studies, 1(2), 164-182. http://dx.doi.org/10.1108/20400701011073473

Piprek, G., Dlamini, P.,, \& Coetzee, G. (2004). Financial literacy scoping study and strategy project.

Prahalad, C. K., \& Hamel, G. (2006). The core competence of the corporation. In D. Hahn \& B. Taylor (Eds.), Strategische unternehmungsplanung — strategische unternehmungsführung (pp. 275-292). Berlin/Heidelberg: Springer-Verlag. http://dx.doi.org/10.1007/3-540-30763-X_14

Rahmandoust, M., Shah, I., Norouzi, M., Hakimpoor, H., \& Khani, N. (2011). Teaching financial literacy to entrepreneurs for sustainable development. OIDA International Journal of Sustainable Development, 2(12), 61-66.

Remund, D. L. (2010). Financial literacy explicated: The case for a clearer definition in an increasingly complex economy. Journal of Consumer Affairs, 44(2), 276-295. http://dx.doi.org/10.1111/j.1745-6606.2010.01169.x

Sabri, M. F., \& MacDonald, M. (2010). Savings behavior and financial problems among college students: The role of financial literacy in Malaysia. Cross-Cultural Communication, 6(3), 103-110.

Sefiani, \& Bown. (2013). What influences the success of manufacturing SMEs? A perspective from Tangier. International Journal of Business and Social Science, 4(7).

Spinelli, S., Timmons, J. A., \& Adams, R. J. (2011). New venture creation: Entrepreneurship for the 21 st century (9th ed.).

Sulaiman, N. (2014). Clarifying the financial literacy dimensions for the performance of small and medium enterprises. Paper presented at the Economic Forum of Entrepreneurship \& International Business, London University Institute in Paris, Paris, France.

Tamimi, H. A. H. a.-., \& Kalli, A. A. B. (2009). Financial literacy and investment decisions of UAE investors. Journal of risk finance: The convergence of financial products and insurance, 10(5), 500-516.

USAID. (2009). Development of strategy options for SME financial literacy - Final Report. Retrieved from http://pdf.usaid.gov/pdf_docs/PNADP093.pdf

Vitt, L. A., Anderson, C., Kent, J., Lyter, D. M., Siegenthaler, J. K., \& Ward, J. (2000). Personal finance and the rush to competence: Financial literacy education in the U.S.: A national field study commissioned and supported by the Fannie Mae Foundation. Middleburg,Virginia: ISFS, Institute for Socio-Financial 
Studies.

Wiklund, J., \& Shepherd, D. (2005). Entrepreneurial orientation and small business performance: A configurational approach. Journal of Business Venturing, 20(1), 71-91. http://dx.doi.org/10.1016/j.jbusvent.2004.01.001

Williamson, K., \& Asla, T. (2009). Information behavior of people in the fourth age: Implications for the conceptualization of information literacy. Library \& Information Science Research, 31(2), 76-83. http://dx.doi.org/10.1016/j.lisr.2009.01.002 
Eniola, A. A., \& Entebang, H. 